\title{
Acute kidney injury on admission to the intensive care unit: where to go from here?
}

\author{
Marlies Ostermann
}

\author{
Guy's and St Thomas Hospital, Department of Critical Care, Westminster Bridge Road, London SE1 7EH, UK \\ Corresponding author: Marlies Ostermann, Marlies.Ostermann@gstt.nhs.uk
}

Published: 7 Nov 2008

Critical Care 2008, 12:189 (doi:10.1186/cc7096)

This article is online at: http://ccforum.com/content/12/6/189

(c) 2008 BioMed Central Ltd

See related research by Kolhe et al., http://ccforum.com/content/12/S1/S2

\section{Abstract}

Acute kidney injury (AKI) is a common problem, especially in critically ill patients. In Critical Care, Kolhe and colleagues report that $6.3 \%$ of 276,731 patients in 170 intensive care units (ICUs) in the UK had evidence of severe AKI within the first 24 hours of admission to ICU. ICU and hospital mortality as well as length of stay in hospital were significantly increased. In light of this serious burden on individuals and the health system in general, the following commentary discusses the current state of knowledge of $\mathrm{AKI}$ in ICU and calls for more attention to preventive strategies.
Acute kidney injury (AKI) has been the focus of numerous publications and research projects in the past 5 years [1-4], including the study by Kolhe and colleagues [1] in Critical Care. Interestingly, as facts about AKI and its impact on prognosis emerged, areas of uncertainty and controversy became apparent $[5,6]$. It is now well known that AKI affects a large number of patients (although the exact incidence is variable), that $\mathrm{AKI}$ per se is associated with an increased risk of death, and that patients who need renal replacement therapy (RRT) have a higher risk of dying [2-4,7,8]. There is also evidence that $\mathrm{AKI}$ is a dynamic process, with many patients progressing through different stages of severity, and that early AKI appears to have a better prognosis than late AKI [7]. Numerous studies have identified factors that influence the prognosis of patients with $\mathrm{AKI}$, including inherent patient characteristics as well as modifiable factors (ie, nephrotoxic drugs, fluid status, haemodynamics) and non-patient related aspects like size of ICU and type of hospital [2-4].

Despite this progress, several areas in the field of AKI remain uncertain, the issue of RRT being a particularly controversial one [5]. There is wide variation in clinical practice regarding mode, indication, timing, dose and provision of RRT [9]. Despite a widely held perception that a continuous mode may be better for critically ill patients with AKI, especially those with haemodynamic instability, clinical studies have failed to show a consistent survival advantage for patients on continuous RRT compared to intermittent haemodialysis [10]. The Hemodiafe Study (randomized controlled trial comparing intermittent haemodialysis with continuous haemodiafiltration in 21 centres in France) not only showed similar mortality rates in both groups but also confirmed that nearly all patients with $\mathrm{AKI}$ as part of multiple-organ dysfunction syndrome could be treated with intermittent haemodialysis provided strict guidelines were used to achieve tolerance and metabolic control [11].

In a landmark study, Ronco and colleagues [12] made a strong case for dosing RRT (the more the better). However, when challenged in subsequent studies, this conclusion could not always be confirmed. Most recently, the Acute Renal Failure Trial Network study demonstrated in a randomized controlled multicenter fashion that intensive renal support in critically ill patients with AKI did not decrease mortality, improve recovery of kidney function or reduce the rate of non-renal organ failure compared to less intensive therapy [13].

In view of these uncertainties about 'best clinical practice' it is not surprising that the mortality associated with $\mathrm{AKI}$ in critically ill patients has not substantially changed during the past few decades despite increasing international efforts and advances in medical knowledge [14]. Lack of a uniform definition for AKI and lack of evidence-based guidelines have been blamed for 
some of the inconsistencies and poor progress. Formation of the international AKI network group, design of the RIFLE criteria and later the AKI classification and plans for streamlined focussed research are major steps in the right direction to tackle the problems associated with established AKI [6].

The study by Kolhe and colleagues in Critical Care illustrates that we may need to focus our attention also on the time before AKI has developed. Kolhe and colleagues show that $6.3 \%$ of 276,731 patients admitted to 170 ICUs in the UK during a 10 year period had evidence of severe AKI (serum creatinine $\geq 300 \mu \mathrm{mol} / \mathrm{L}$ and/or urea $\geq 40 \mathrm{mmol} / \mathrm{L}$ ) during the first 24 hours in ICU [1]. Their ICU and hospital mortality as well as stay in hospital were significantly increased. Moreover, among survivors, requirement for in-hospital care was even higher. The study also showed that a perfect mortality prediction model is still missing. As addressed by the authors, the study has some weaknesses (arbitrary definition of severe AKI, potential risk that some patients classified as AKI in fact had advanced chronic kidney disease, and no information on the number of patients treated with RRT). However, there are important messages: $6.3 \%$ of all ICU patients were admitted with severe derangement of renal function. The exact reasons for renal dysfunction are not given and may not be known but the question remains whether AKI could have been prevented prior to transfer to ICU. Chertow and colleagues [15] previously showed that even small changes in serum creatinine by $\geq 0.3 \mathrm{mg} / \mathrm{dL}$ ( $\geq 26 \mu \mathrm{mol} / \mathrm{L}$ ) whilst in hospital were independently associated with an increased risk of dying. Given the serious implications of any degree of AKI on the individual and the health system, and the lack of curative therapies for AKI, it may be necessary to shift our attention more to the actual way we look after patients at risk of $\mathrm{AKI}$, that is, how we recognise high-risk patients and prevent AKI. This call for 'attention to basics' includes general measures like education and training of nursing and medical staff, emphasis on the importance of the clinical examination, attention to drugs, drug dosing and nutrition, and early consultation with specialists in the field. The success of these simple non-technical steps depends on combined efforts by anybody looking after patients in hospital. The overall action plan to reduce the burden of AKI needs to incorporate these preventive strategies as well as regular review of clinical practice, in parallel with international collaboration and focussed research into drug therapies and technologies.

\section{Competing interests}

The author declares that they have no competing interests.

\section{References}

1. Kolhe NV, Stevens PE, Crowe AV, Lipkin GW, Harrison DA: Case mix, outcome and activity for patients with severe acute kidney injury during the first 24 hours after admission to an adult general critical care unit: application of predictive models from a secondary analysis of the ICNARC Case Mix Programme Database. Crit Care 2008, 12(Suppl 1):S2.
2. Uchino S, Kellum JA, Bellomo R, Doig GS, Morimatsu H, Morgera S, Schetz M, Tan I, Bouman C, Macedo E, Gibney N, Tolwani A, Ronco C, Beginning and Ending Supportive Therapy for the Kidney (BEST Kidney) Investigators: Acute renal failure in critically ill patients: a multinational, multicenter study. JAMA 2005, 294:813-818.

3. Ostermann M, Chang RW: Acute kidney injury in the intensive care unit according to RIFLE. Crit Care Med 2007, 35:1837-1843.

4. Mehta RL, Pascual MT, Soroko S, Savage BR, Himmelfarb J, Ikizler TA, Paganini EP, Chertow GM, for the Program to Improve Care in Acute Renal Disease (PICARD): Spectrum of acute renal failure in the intensive care unit: the PICARD experience. Kidney Int 2004, 66:1613-1621.

5. Gibney N, Hoste E, Burdmann EA, Bunchman T, Kher V, Viswanathan R, Mehta RL, Ronco C: Timing of initiation and discontinuation of renal replacement therapy in AKI: unanswered key questions. Clin J Am Soc Nephro/ 2008, 3:876-880.

6. Kellum JA, Mehta RL, Levin A, Molitoris BA, Warnock DG, Shah SV, Joannidis M, Ronco C, Acute Kidney Injury Network (AKIN): Development of a clinical research agenda for acute kidney injury using an international interdisciplinary three-step modified Delphi process. Clin J Am Soc Nephrol 2008, 3:887-894.

7. Hoste EA, Clermont G, Kersten A, Venkataraman R, Angus DC, De Bacquer D, Kellum JA: RIFLE criteria for acute kidney injury are associated with hospital mortality in critically ill patients: a cohort analysis. Crit Care 2006, 10:R73.

8. Metnitz PGH, Krenn CG, Steltzer H, Lang T, Ploder J, Lenz K, Le Gall JR, Druml W: Effect of acute renal failure requiring renal replacement therapy on outcome in critically ill patients. Crit Care Med 2002, 30:2051-2058.

9. Ricci Z, Ronco C, D'Amico G, DeFelice R, Rossi S, Bolgan I, Bonello M, Zamperetti N, Petras D, Salvatori G, Dan M, Piccinni P: Practice patterns in the management of acute renal failure in the critically ill patient: an international survey. Nephrol Dial Transplant 2006, 21:690-696.

10. Rabindranath K, Adams J, Macleod AM, Muirhead N: Intermittent versus continuous renal replacement therapy for acute renal failure in adults. Cochrane Database Syst Rev 2007, 3:CD003773.

11. Vinsonneau C, Camus C, Combes A, Costa de Beauregard MA, Klouche K, Boulain T, Pallot JL, Chiche JD, Taupin P, Landais P, Dhainaut JF, Hemodiafe Study Group: Continuous venovenous haemodiafiltration versus intermittent haemodialysis for acute renal failure in patients with multiple-organ dysfunction syndrome: a multicentre randomised trial. Lancet 2006, 368:379-385.

12. Ronco C, Bellomo R, Homel $P$, Brendolan $A$, Dan M, Piccinni $P, L a$ Greca G: Effects of different doses in continuous veno-venous haemofiltration on outcomes of acute renal failure: a prospective randomised trial. Lancet 2000, 356:26-30.

13. VA/NIH Acute Renal Failure Trial Network, Palevsky PM, Zhang JH, O'Connor TZ, Chertow GM, Crowley ST, Choudhury D, Finkel K, Kellum JA, Paganini E, Schein RM, Smith MW, Swanson KM, Thompson BT, Vijayan A, Watnick S, Star RA, Peduzzi P: Intensity of renal support in critically ill patients with acute kidney injury. N Engl J Med 2008, 359:7-20.

14. Ympa YP, Sakr Y, Reinhart K, Vincent JL: Has mortality from acute renal failure decreased? A systematic review of the literature. Am J Med 2005, 118:827-832.

15. Chertow GM, Burdick E, Honour M, Bonventre JV, Bates DW: Acute kidney injury, mortality, length of stay, and costs in hospitalized patients. J Am Soc Nephrol 2005, 16:3365-3370. 